\title{
SOCIAL SECURITY
}

\section{AND MEDICARE POLICY FROM THE PERSPECTIVE OF GENERATIONAL ACCOUNTING}

\author{
Alan J. Auerbach \\ University of Pennsylvania and NBER \\ Jagadeesh Gokhale \\ Federal Reserve Bank of Cleveland
}

Laurence J. Kotlikoff

Boston University and NBER

\section{EXECUTIVE SUMMARY}

Our previous studies (Auerbach, Gokhale, and Kotlikoff, 1991 and 1992) and Kotlikoff (1992) introduced the concept of "generational accounting ${ }^{\prime \prime}$ a method of determining how the burden of fiscal policy falls on different generations. It found that fiscal policy in the United States is out of balance, in terms of projected generational burdens. This means that either current generations will bear a larger share (than we project under current law) of the burden of the government's spending or that future generations will have to pay, on average, at least 21 percent more,

This paper has been prepared for the annual NBER conference on Tax Policy and the Economy, Washington D.C., November 1991. Sections of this paper draw on Auerbach, Gokhale, and Kotlikoff (1991, 1992) and Kotlikoff (1992). 
on a growth-adjusted basis, than will those generations who have just been born.

These conclusions were based on relatively optimistic assumptions about the path of social security and Medicare policies, namely that the accumulation of a social security trust fund would continue and that Medicare costs would not rise as a share of GNP. In this paper, we simulate the effects of realistic alternative paths for social security and Medicare. Our results suggest that such alternative policies could greatly increase the imbalance in generational policy, making not only future generations pay significantly more, but current young Americans as well. For example, continued expansion of Medicare in this decade alone could double the 21 percent imbalance figure if the bill for this Medicare growth is shifted primarily to future generations.

\section{INTRODUCTION}

Recent years have witnessed a growing skepticism about the use of the fiscal deficit to gauge the stance of economic policy. Many economists as well as noneconomists are questioning whether a single number, that relates primarily to the government's current cash flow, is the kind of measure needed to understand the longer term effects of fiscal policy on saving, investment, and growth. They also ask whether the deficit can tell us how we are treating different generations, both those currently alive and those yet to come. Doubts about the deficit have been accentuated by the aging of the U.S. population, with its attendant increase in the number of retirees dependent on workers for pay-as-you-go spending and transfer programs.

In recognition of these concerns about the demographic transition, the U.S. federal government began, in 1983, to accumulate a large social security trust fund to help finance the social security benefits of the "baby boom" generation. But this break with short-term, pay-as-you-go financing also raised new questions about using the unified federal deficit, which includes social security, as a measure of fiscal policy. If funds for the future need to be accumulated by the social security system, then shouldn't such accumulations be excluded from the overall deficit measure? The federal government's response, as expressed in the 1990 budget agreement, has been to exclude social security from future calculations of the deficit. This has not prevented public discussion of the deficit inclusive of social security. Nor has it put to rest the concern that government spending is now larger and will continue to be larger and that taxes are now smaller and will continue to be smaller than they would in the absence of the social security surpluses; that is, it has not put to rest the 
concern that the federal government is "using" the large pay as-you-go social security surpluses to offset large on-budget deficits.

This is but one example of the ambiguity of the deficit and the deficiency of any single deficit measure as a gauge of the fiscal burden faced by different generations. Although one response to this deficiency has been to construct different deficits for different purposes, such constructs are clearly ad hoc in nature and require continual "refinements" to prevent perverse results. For example, if the social security system is excluded from the budget for deficit purposes, how does one deal with changes in income taxes that are induced by changes in social security taxes? Should such changes in off-budget taxes be permitted to alter the on-budget deficit?

The key economic question associated with fiscal deficits is this: Which generation will pay for what the government spends? No version of the government's budget deficit provides this information. As we discuss later, an increase in the deficit does not necessarily signal a shift in the fiscal burden to future generations. Moreover, policies that dramatically alter the intergenerational distribution of fiscal burdens may do so without inducing any change whatsoever in the measured deficit.

In earlier papers (Auerbach, Gokhale, and Kotlikoff, 1991 and 1992) and in a book (Kotlikotf, 1992), we developed an alternative to the deficit--generational accounting--and showed how this new approach could be used to assess fiscal policy and its distributional impact with respect to different generations. Our previous analysis stressed that generational accounts are quite informative about the effects of changes in tax and transfer policies on the burdens of different generations. This paper uses generational accounting to analyze potential changes in the federal government's most important transfer program, the Old Age Survivors, Disability, and Health Insurance (OASDHI), which includes the old-age Social Security pension system and Medicare. This component of the federal budget has grown much more rapidly than other components in recent years. If current trends continue, OASDHI will continue to grow relative to the economy due to the increasing share of the elderly in the population and the rapid increase in real medical costs.

Before turning to such policy analysis, we briefly review the generational accounting methodology, which is discussed more fully in Auerbach, Gokhale, and Kotlikoff $(1991,1992)$.

\section{THE GENERATIONAL ACCOUNTING APPROACH}

The basic idea behind generational accounting is that generations currently alive and those yet to be born must pay for the time-path of the 
government's expenditures on goods and services less the external resources the government has to cover these expenditures (its net wealth). This is the government's intertemporal budget constraint. The constraint reminds us of the zero-sum nature of paying for the government's expenditures; if generations currently alive pay less, generations yet to come will be forced to pay more. It also reminds us that changes in fiscal policy today are likely to necessitate changes in the future. We express the government's intertemporal budget constraint in present value, with the initial value of government liabilities and the present value of future spending being equal to the sum of the present values of each generation's burden. Regardless of the year in which such burdens are imposed, emphasizing the present value burdens of different generations neutralizes the timing problems inherent in annul deficit measures, and allows us to summarize in a compact form the likely effects of fiscal policy on individuals through time.

The analysis is forward-looking in that it calculates only the future fiscal burdens that each generation faces. Because we are interested in the issue of generational imbalance in fiscal policy, we treat current and future generations separately when analyzing a particular fiscal policy path. For current generations, we calculate the burden under the particular fiscal scenario. For future generations, we calculate the total present value of payments required to balance the government's intertemporal budget constraint. One cannot say how this aggregate burden on future generations will be distributed across these future generations. For purposes of illustrating the size of the burden likely to be imposed on future generations relative to that likely to be imposed on current generations, we assume that the burden on each successive future generation remains fixed as a fraction of the lifetime income of that generation; that is, the absolute fiscal burden of successive generations grows at the rate of growth of their lifetime incomes, which we take to be the rate of growth of productivity.

To calculate the burden faced by a member of an existing generation, we first project the net payments to the government in each future year for a representative member of that generation (distinguishing males and females) and then take the present value of such payments. By net payments we mean all taxes paid to, less all transfers received from, government at the federal, state, and local levels. Payments include not only direct taxes such as income and property taxes, but also indirect business taxes, corporate taxes, and seignorage. Transfers include Medicare, Medicaid, Food Stamps, Social Security Benefits, and so on.

The present value calculation for each representative individual discounts future payments not only for interest, but also mortality: An 
individual's future burden is reduced by the probability that he or she will not be alive when that burden occurs. Given our assumption that members of each generation (distinguished only by sex) face the same survival probabilities, multiplying individual payments in each year by the generation's projected surviving population for that year provides a measure of that generation's payment, the separate components of which are benchmarked to aggregates from the National Income and Product Accounts.

Once burdens for current generations have been calculated, those faced by future generations are estimated as a residual, based on the fiscal balance requirement and the assumption that the remaining fiscal burden be borne proportionally. Policy changes affect the projected net payments faced by current generations and, through the fiscal balance requirement, the burden on future generations as well.

Because the accounts are forward-looking, they do not consider the net payments made in the past. The present value of future net payments, which are positive for young and middle-aged existing generations, are negative for older generations, who are largely retired and facing lower labor income taxes while at the same time receiving social security benefits and Medicare. Thus, the level of an existing generation's account does not indicate how well or poorly that generation has fared at the hands of the government. We therefore focus on the changes in each generation's account that are induced by alternative policies.

\section{CONSTRUCTION OF GENERATIONAL ACCOUNTS}

The construction of generational accounts is a two-step process. The first step entails projecting each currently living generation's average taxes less transfers in each future year during which at least some members of the generation will be alive. The second step converts these projected average net tax payments into a present value using an assumed discount rate and taking into account the probability that the generations' members will be alive in each of the future years (i.e., actuarial discounting for both mortality and interest).

In projecting each currently living generation's taxes and transfers, we consider first their taxes and transfers in the base year, in this case, 1989. The totals of the different taxes and transfers in the base year are those reported by the National Income and Product Accounts. As described in detail in Auerbach, Gokhale, and Kotlikoff (1991), these totals of base year taxes and transfers are distributed to the different generations ac- 
cording to their ages and sexes based on cross-section survey data. These data include the Bureau of the Census' Survey of Income and Plan Participation and the Bureau of Labor Statistics' Survey of Consumer Expenditures. The distribution of future taxes and transfers by age and sex is assumed to equal that in the current year with adjustments for growth and projected changes in policy.

Because the government already forecasts the totals of its various taxes and transfers for many years ahead, the additional work involved in generational accounting is primarily in allocating these projected totals by age and sex. Thus, although there are a few additional elements and the requisite projections extend farther into the future, generational accounting uses mostly the same numbers the government uses, only in a different manner.

The calculations presented here assume a 6.00 percent real rate of discount and a productivity growth rate of 0.75 percent. The rate of productivity growth is based on recent U.S. experience. The discount rate is higher than the rate of return on government obligations, reflecting the fact that future government receipts and expenditures are risky. I The estimates also incorporate the mortality probabilities embedded in the Social Security Administration's projections of the U.S. population by age and sex. As discussed in Auerbach. Gokhale, and Kotlikoff (1991), the absolute value of the generational accounts is sensitive to the choice of rates of discount and growth as well as rates of birth and death. But for many of the questions of interest, such as the fiscal burden being imposed on future generations relative to that being shouldered by current generations, the results are quite robust to reasonable departures from baseline assumptions.

As mentioned, inferring the fiscal burden on future generations requires not only knowing the sum total of generational accounts of current generations, but also the projected present value of the government's expenditures on goods and services as well as the government's initial net wealth position. As described in Auerbach, Gokhale, and Kotlikoff (1991), the government's net wealth is estimated in a manner consistent with the government sector deficit reported in the National Income Accounts. The

\footnotetext{
${ }^{1}$ As we discussed in our 1991 paper, the appropriate discount rate to use depends on the risk characteristics of the flows being discounted. (A similax point has been made by Bohn, 1991). If government receipts and expenditures were roughly proportional to aggregate Ructuations in income, then the private sector discount rate, measured by the real beforetax rate of return, would seem the appropriate discount rate to use. We use a somewhat lower tate to reflect the existence of countercyclical government policy. In principle, one would also discount separate components of expenditures and net receipts using different rates.
} 
present value of government expenditures is calculated by projecting current expenditures into the future taking into account those expenditure elements that are sensitive to the demographic structure. For example, our projections take into account the decline in per capita spending on education that is likely to arise as the school-age population declines relative to the total population.

Our baseline generational accounts reflect policy as of 1989 (prior to the 1990 budget agreement). They show that a newborn male faced a net payment to the government of $\$ 73,700$, reflecting present values of $\$ 85,300$ of tax payments and $\$ 11,600$ of transfers received. For females, the comparable figures are $\$ 36,400$ in net present value, comprising $\$ 54,700$ in taxes and $\$ 18,300$ in transfers. The lower taxes for females primarily reflect their lower rate of labor force participation, and hence lower income and payroll taxes. The higher transfers reflect greater female longevity and the concentration of female-headed households in circumstances of poverty. Together, Medicare and social security account for nearly half of all transfers received by males, and over a third of those received by females.

Based on our estimates of initial government wealth and the projections of the effects of this baseline fiscal policy on existing generations, we find that, as of 1989, generational policy was out of balance in the sense that the fiscal burden on future generations was 21 percent larger than that on 1989 male and female newborns, who are assumed to fall under the current policy regime. As the net lifetime payments newborns are projected to make represent almost 40 percent of their lifetime incomes, this imbalance in generational policy translates into an added burden of nearly one tenth of the income of members of future generations.

An alternative way of measuring how far the current regime is out of generational balance is the change in any particular fiscal instrument that would be necessary to bring this 21 percent excess to zero-to make the "new" current policy sustainable without further adjustment. Our calculations suggest that an immediate and permanent increase in the average income tax rate of 5.3 percent (just under 1 percentage point) would suffice. If, instead, payroll taxes were used to equalize the burden, they would have to rise by 7.8 percent, or about 1 percentage point. Alternatively, a rise in sales taxes of 10.2 percent (just over 1 percentage point) or a 14.3 percent rise (nearly 4 percentage points) in capital income taxes would be required. Although any of these fiscal instruments (or many others) could be used to provide intergenerational balance, each policy change would lead to a different burden on current and future generations. The most favorable to the young and future genera- 
tions are sales taxes, more of which would be paid by older individuals. At the other extreme, not surprisingly, are payroll taxes. Hence, generational balance may be achieved with a range of impacts on particular generations. ${ }^{2}$

\section{GENERATIONAL ACCOUNTING AND DEFICITS}

The usefulness of generational accounting is immediately clear when one compares the effects of specific fiscal polices on deficits and generational accounts. Policies that change the pattern of generational burdens need not affect the deficit, while other policies may change the deficit without affecting the pattern of generational burdens. This is illustrated by Table 1 (reprinted by permission from Kotlikoff 1992), which present simulations of the effects of four different, but not unusual, policies.

The first of these policies is a five-year, 20 percent reduction in the average federal income tax rate, with the tax rate increased above its initial value after five years to maintain a constant debt-to-GNP ratio. This policy would raise the deficit and shift the fiscal burden to young and future generations, not a surprising result. The second policy-an immediate and permanent 20 percent increase in social security retirement and disability benefits financed on a pay-as-you-go basis by increases in payroll taxes - would induce a quite similar shifting of fiscal burdens without any change in the time path of measured deficits (including or excluding the social security system). The third policy involves an equal revenue switch in tax structure, a permanent 30 percent cut in payroll taxes financed by increased sales taxes, which, again, shifts generational burdens without changing the deficit.

The final policy illustrated in Table 1 involves the elimination of the discount that presently exists in the price of existing assets as a result of investment incentives. Removing this discount (as would be accomplished by extending the tax treatment of new assets to existing assets) is essentially a windfall grant to owners of existing capital. We assume in the simulation that this grant is paid for by a permanent increase in capital income tax rates, a policy shift that transfers resources from the young (who, on average, have not yet accumulated significant wealth) to the old (who, on average, have).

As the simulations in this section indicate, the generational effects of a variety of realistic policies cannot be determined by looking at deficits. We turn now to an examination of several social security and Medicare policies that may actually be adopted through time.

i See Auerbach, Gokhale, and Kotlikoff (1992) for further discussion. 
TABLE 1.

Changes in Generational Accounts Arising from Four Hypothetical Policies (present value, thousands of dollars).

\begin{tabular}{|c|c|c|c|c|}
\hline & $\begin{array}{l}\text { 5-year } \\
\text { tax cut }\end{array}$ & $\begin{array}{c}20 \text { percent } \\
\text { social security } \\
\text { benefit increase }\end{array}$ & $\begin{array}{l}\text { Shifting from } \\
\text { payroll to sales } \\
\text { and excise taxes }\end{array}$ & $\begin{array}{l}\text { Eliminating } \\
\text { investment } \\
\text { incentives }\end{array}$ \\
\hline \multicolumn{5}{|l|}{ Males } \\
\hline \multicolumn{5}{|l|}{ Ages } \\
\hline 0 & 1.9 & 2.7 & 1.0 & 0.9 \\
\hline 10 & 3.2 & 3.9 & -1.3 & 1.5 \\
\hline 20 & 2.2 & 5.5 & -6.5 & 2.3 \\
\hline 30 & -0.3 & 5.2 & -8.8 & 2.1 \\
\hline 40 & -2.7 & 2.4 & -7.5 & 0.2 \\
\hline 50 & -4.4 & -2.7 & -3.8 & -2.5 \\
\hline 60 & -5.0 & -10.2 & 0.7 & -4.7 \\
\hline 70 & -2.6 & -11.9 & 3.4 & -5.0 \\
\hline 80 & -1.6 & -7.3 & 2.8 & -4.0 \\
\hline \multicolumn{5}{|l|}{ Future } \\
\hline generations & 1.9 & 3.1 & 0.4 & 0.2 \\
\hline \multicolumn{5}{|l|}{ Females } \\
\hline \multicolumn{5}{|l|}{ Ages } \\
\hline 0 & 1.0 & 1.0 & 3.5 & 0.4 \\
\hline 10 & 1.7 & 1.5 & 3.2 & 0.6 \\
\hline 20 & 0.7 & 1.9 & 1.5 & 0.8 \\
\hline 30 & -0.2 & 0.9 & 1.8 & 1.2 \\
\hline 40 & -1.0 & -1.0 & 2.4 & 0.6 \\
\hline 50 & -1.9 & -4.5 & 3.1 & -0.5 \\
\hline 60 & -2.1 & -10.0 & 3.9 & -1.8 \\
\hline 70 & -1.5 & -11.0 & 3.9 & -2.4 \\
\hline 80 & -0.9 & -7.5 & 2.8 & -2.4 \\
\hline \multirow{2}{*}{$\begin{array}{l}\text { Future } \\
\text { gerterations }\end{array}$} & & & & \\
\hline & 1.0 & 1.1 & 3.8 & 0.1 \\
\hline
\end{tabular}

\section{THE GENERATIONAL IMPACTS OF SOCIAL POLICIES}

\section{A. Social Security's OASDI Program}

We first consider policies to alter the structure of the OASDI (nonMedicare) portion of the social security system. As a result of the increases in payroll taxes mandated by the 1983 changes, this program has in recent years been running large cash flow surpluses of roughly 100 billion dollars per year. Although these accumulations were pianned to help offset benefit payments in the decades to come, their existence, 
combined with historically high payroll tax rates, has lent force to arguments for reducing payroll taxes. Cutting payroll taxes is not, in itself, a. full description of a fiscal policy, however; payroll tax cuts alone would. cause a violation of the government's fiscal balance requirement. A complete policy specification also requires a compensating change either in net government receipts or spending (or both). This section presents simulations for four such policies and their effects on the fiscal burdens of different generations.

The first of the four policies considered is a proposal to cut the social security payroll tax rate over the next three decades and to increase the tax rate thereafter. The second policy involves the same reduction in payroll taxes (through the year 2020) as in the first simulation, but rather than raise tax rates after 2020 , this policy reduces social security benefits beginning in that year by the same amount that payroll taxes otherwise would have increased. The third policy entails the indirect dissipation of the social security trust fund though an increase in government spending over the next three decades equal, on an annual basis, to the social security surplus. Over these decades funds to pay for the increased government spending are "borrowed" so that in 2020 the additional accumulated federal debt is equal in magnitude to the social security trust fund. The fourth policy is an immediate and permanent switch from payroll tax finance to income tax finance of social security.

The first column of Table 2 indicates what reducing and then increasing payroll taxes will do to the burdens placed on different generations. The policy provides windfalls to Americans currently alive, with the exception of the very old and the very young. Those currently aged thirty to forty receive the largest windfalls, roughly $\$ 3,000$ for males and $\$ 1,500$ for females. These gains come at the expense of children currently under age ten as well as future individuals. If all future Americans are treated uniformly, up to the growth adjustment, their lifetime net payments will rise by $\$ 6,100$, in the case of males, and $\$ 3,000$, in the case of females.

Enactment of a policy that promises to raise future taxes to pay for current tax cuts does not ensure that such taxes will actually be raised. The government might use an alternative method to restore fiscal balance. For example, the necessary increase in net payments might take the form of a cut in social security benefits. Such a policy, depicted in the second column of Table 2 , reduces by about one third for males and by about two thirds for females the gains enjoyed under the initial policy. Females lose relatively more because their share of social security benefits is larger than is their share of payroll tax payments.

The third column in Table 2 shows what happens if the federal govern- 
TABLE 2.

Changes in Generational Accounts from Four Social Security Policies (present value, thousands of dollars).

\begin{tabular}{|c|c|c|c|c|}
\hline & $\begin{array}{l}\text { Immediate } \\
\text { payroll } \\
\text { tax cuts } \\
\text { financed by } \\
\text { future tax } \\
\text { increases }\end{array}$ & $\begin{array}{l}\text { Immediate } \\
\text { payroll } \\
\text { tax cuts } \\
\text { financed by } \\
\text { benefit } \\
\text { reductions }\end{array}$ & $\begin{array}{l}\text { Dissipating } \\
\text { the } \\
\text { social security } \\
\text { trust fund }\end{array}$ & $\begin{array}{c}\text { Switching } \\
\text { from payrolt } \\
\text { to income } \\
\text { tax finance }\end{array}$ \\
\hline \multicolumn{5}{|l|}{ Males } \\
\hline \multicolumn{5}{|l|}{ Ages } \\
\hline 0 & 1.3 & 0.3 & 4.1 & -2.4 \\
\hline 10 & -0.2 & -0.6 & 4.0 & -3.6 \\
\hline 20 & -2.3 & -1.8 & 2.9 & -4.4 \\
\hline 30 & -3.4 & -2.2 & 1.5 & -1.0 \\
\hline 40 & -3.2 & -2.5 & 0.6 & 4.4 \\
\hline 50 & -2.0 & -1.8 & 0.2 & 8.4 \\
\hline 60 & -0.7 & -0.7 & 0 & 9.6 \\
\hline 70 & -0.1 & -0.1 & 0 & 7.7 \\
\hline 80 & 0 & 0 & 0 & 4.5 \\
\hline \multicolumn{5}{|l|}{ Future } \\
\hline generations & 6.1 & 3.8 & 5.2 & -2.5 \\
\hline \multicolumn{5}{|l|}{ Females } \\
\hline \multicolumn{5}{|l|}{ Ages } \\
\hline 0 & 0.6 & 0.4 & 1.9 & -2.0 \\
\hline 10 & -0.3 & -0.1 & 1.9 & -3.1 \\
\hline 20 & -1.4 & -0.6 & 1.5 & -4.2 \\
\hline 30 & -1.7 & -0.5 & 0.9 & -2.0 \\
\hline 40 & -1.5 & -0.6 & 0.4 & 1.3 \\
\hline 50 & -1.0 & -0.5 & 0.1 & 4.2 \\
\hline 60 & -0.4 & -0.4 & 0 & 5.6 \\
\hline 70 & 0 & 0 & 0 & 4.8 \\
\hline 80 & 0 & 0 & 0 & 2.2 \\
\hline \multicolumn{5}{|l|}{ Future } \\
\hline generations & 3.0 & 2.2 & 2.4 & -2.2 \\
\hline
\end{tabular}

ment indirectly dissipates the social security surplus by raising its spending beyond the amount projected in the baseline generational accounts. In the simulation, the government continues to accumulate its social security trust fund, but it also borrows to pay for additional spending with the annual amount of the borrowing equal in size to the annual social security surplus. We assume this process of deficit-financed increased spending continues through 2020 , and that after 2020 the govern- 
ment raises income taxes to pay interest less an adjustment for growth on the additional accumulated official debt.

This policy has quite different effects from those in the previous simulations, since, unlike policies that do not change direct government spending, increases in government spending may eventuate in an increase in the sum of all generational accounts. Here, this added burden is borne by all generations who will be alive to service the extra debt, with the greatest burden on those currently young and those yet to be born. How this translates into the net impact on each generation depends on the size and distribution of the benefits of the added spending. Certainly if the benefits are spread over only those currently alive, the unborn will lose.

The final simulation in Table 2 shows the effects of a change in the method of financing social security benefits. Over the years some have argued that the connection between payroll taxes and OASDI benefits is sufficiently weak that there is little reason to rely on the payroll tax as a source of finance. The policy change considered here would replace the payroll tax with the income tax as the method of finance, immediately and permanently. Although such a change has been advocated for a variety of reasons, including a desire to use a more progressive source of revenue, our simulation considers only the generational effects of the switch. We find that those under forty stand to win, and those over forty stand to lose, because income taxes are levied on income from assets as well as income from labor, and older individuals receive a bigger share of asset income than labor income.

The generational implications of using general revenue finance to pay for social security are spelled out in the last column of Table 2 . On average, sixty-year-old males and females would be forced to pay $\$ 9,600$ and $\$ 5,600$ more, respectively. Forty year-old males and females would suffer respective losses of $\$ 4,400$ and $\$ 1,300$. In contrast, males and females who are now age ten would benefit by more than $\$ 3,000$ each. The policy also would represent more than a $\$ 2,000$ lifetime net payment break to future generations.

In summary, the results in this table show that one cannot simply analyze the effects of a cut in payroll taxes; it is necessary to specify what replaces these taxes. The simulations suggest four possible routes: Increased payroll taxes in the future, reduced benefits in the future, reductions in government spending, and replacement with income taxes. Each has its own effects on the generational fiscal burden.

\section{B. Medicare Policy}

Many observers have worried about the rising level of health care costs in the United States, which spends a much larger fraction of GNP on 
health care than any other OECD country. After the United States, Canada is the country with the highest per capita health care spending, but the Canadians spend almost 30 percent less per person. At present, about $\$ 0.12$ of every dollar of U.S. output goes to health care, compared with $\$ 0.06$ in 1960 . By the turn of the century the figure is projected to be $\$ 0.17$. And if the growth of health care is unabated, the figure will reach $\$ 0.37$ by the year 2030 (see Darman 1991).

What explains the rapid growth in real per capita U.S. health expenditures? Since 1960 slightly over half of the growth simply reflects expanded use of health care services and facilities. Another third of the growth is due to the price of medical care rising relative to the prices of other goods and services. And the remaining 11 or so percent of health expenditure growth reflects the aging of the population. This aging of America will, of course, intensify in the years ahead.

The growth of health care expenditures has potentially enormous implications for government outlays and the well-being of different generations. Consider just the federal government's expenditures on Medicare. These payments currently constitute 7 percent of total federal outlays. According to the Office of Management and Budget, Medicare is projected to exceed 30 percent of the federal budget by 2025 . To support Medicare at its current levels alone, either the federal budget would have to grow far beyond its current level of about 20 percent of GNP or the rest of the budget would have to decline by more than 20 percent in real terms.

If Medicare's growth is not curtailed, how will its additional costs be financed? Given its cash-flow accounting, Medicare, like OASDI, will be reporting cash-flow surpluses over most of this decade as the HI (health insurance) component of payroll taxes grows. But by the end of the decade the higher payroll tax receipts will fall short of the increased Medicare spending, leading, in short order, to the exhaustion of the Medicare Trust Fund.

If and when the $\mathrm{HI}$ trust fund is dissipated, the government may raise payroll taxes, or may simply "borrow" from the OASI (Old Age Survivor Insurance) and DI (Disability Insurance) Social Security trust funds. Interfund social security borrowing has occurred in the past, and would delay the eventual need to raise payroll taxes, possibly until the burden of these higher taxes fell primarily on generations not yet born. According to Medicare's actuaries, the HI payroll tax may have to rise by anywhere from 6 to 16 percentage points. Because the combined employeremployee social security payroll tax is currently just over 15 percent, the uninhibited growth of Medicare expenditures could eventually require a doubling of social security taxes. 
The generational accounts considered thus far were based on the assumption (perhaps naive) that medical expenditures will grow no faster than the rest of the economy. In light of the past growth of Medicare, Table 3 considers two alternative growth rates for Medicare expenditures over the 1990s. In the table Medicare outlays in the 1990 s are assumed to grow at either a 2 or 4 percent higher rate than the rest of the economy. After the turn of the century the Medicare growth rate is assumed to equal the economy-wide growth rate. The 2 and 4 percent growth rates bracket the 2.77 rate of growth of health spending in excess of GNP observed between 1960 and 1989 . The 4 percent growth rate is consistent with projections of an increase, over the decade, from 12 to 17 percent in the share of U.S. health care spending relative to GNP.

For each growth rate there are three alternative financing scenarios. The first is that future generations pick up the entire bill for this decade's projected higher Medicare growth. The second is that the growth in Medicare over the next decade is ultimately paid for by a reduction in Medicare benefits starting in the year 2020. The third is that this decade's growth in Medicare is matched, on an annual basis, with increases in HI payroll taxes.

The three scenarios have markedly different implications for both living and unborn generations. Under the first scenario, the burden is entirely shifted onto future generations; all living generations benefit from the growth in Medicare, because they do not have to pay for it. Depending on the growth rate assumed, future generations end up paying from 10 to 23 percent more than in the base case. If Medicare growth is 4 percent, the absolute increase in the bill handed to our male descendants is $\$ 19,400$; it is $\$ 9,000$ for our female descendants. These additional burdens raise substantially the ratio of total net payments of the unborn to those of newborns. Rather than paying 21 percent more than newborns, future generations in the 4 percent growth scenario end up paying almost 50 percent more than newborns.

The second scenario, given in columns 2 and 5 , indicates what happens if, instead of borrowing from the Social Security Trust Fund, Medicare pays for its prospective near-term generosity with longer-term (after 2020 ) benefit cuts. In this case, individuals below age fifty lose, because of the net cuts in Medicare benefits in their retirement. Note also that today's older individuals experience the same large gains from Medicare growth as in the previous financing scenario for the simple reason that, by assumption, the projected Medicare benefit cuts do not begin for thirty years.

The third financing mechanism, which involves annual increases in $\mathrm{HI}$ payroll taxes to pay for the excess Medicare growth, is explored in Col- 
umns 3 and 6 . This scenario hurts an even larger fraction of those alive, but has the smallest effect on members of future generations, whose net payments rise by roughly the same proportion as those for individuals age thirty and under. As in the previous cases, members of older generations, who have essentially retired and ceased paying payroll taxes, enjoy roughly the same gain from the near-term growth in Medicare.

Given the persistent growth of health care costs, one might ask how much more extreme these results would be if Medicare spending grew as a share of GNP not for the next decade but, say, for the next three decades. We repeated the simulations in Table 3 under the assumption

TABLE 3.

Changes in Generational Accounts from Medicare Policies (present value, thousands of dollars).

\begin{tabular}{|c|c|c|c|c|c|c|}
\hline & \multicolumn{3}{|c|}{2 petcent growth rate } & \multicolumn{3}{|c|}{4 percent growth rate } \\
\hline & $\begin{array}{c}\text { Future } \\
\text { generations } \\
\text { pay }\end{array}$ & $\begin{array}{l}\text { Eventual } \\
\text { Medicare } \\
\text { benefit cut }\end{array}$ & $\begin{array}{l}\text { Pay-as- } \\
\text { you-go } \\
\text { finance }\end{array}$ & $\begin{array}{c}\text { Future } \\
\text { generations } \\
\text { pay }\end{array}$ & $\begin{array}{l}\text { Eventual } \\
\text { Medicare } \\
\text { benefit cut }\end{array}$ & $\begin{array}{l}\text { Pay-as } \\
\text { you-go } \\
\text { finance }\end{array}$ \\
\hline \multicolumn{7}{|l|}{ Males } \\
\hline \multicolumn{7}{|l|}{ Ages } \\
\hline 0 & -0.2 & 0.1 & 1.6 & -0.5 & 0.3 & 3.4 \\
\hline 10 & -0.4 & 0.2 & 2.1 & -0.9 & 0.5 & 4.6 \\
\hline 20 & -0.6 & 0.4 & 2.3 & -1.4 & 0.8 & 4.9 \\
\hline 30 & -1.0 & 0.7 & 1.6 & -2.2 & 1.6 & 3.6 \\
\hline 40 & -1.6 & 0.1 & 0.4 & -3.5 & 0.1 & 0.7 \\
\hline 50 & -2.7 & -1.9 & -1.6 & -5.9 & -4.2 & -3.5 \\
\hline 60 & -4.2 & -4.2 & -3.9 & -9.2 & -9.2 & -8.5 \\
\hline 70 & -3.6 & -3.6 & -3.5 & -7.7 & -7.7 & -7.5 \\
\hline 80 & -2.0 & -2.0 & -2.0 & -4.3 & -4.3 & -4.3 \\
\hline \multicolumn{7}{|l|}{ Future } \\
\hline generations & 8.9 & 3.3 & 2.0 & 19.4 & 7.1 & 4.3 \\
\hline \multicolumn{7}{|l|}{ Females } \\
\hline \multicolumn{7}{|l|}{ Ages } \\
\hline 0 & -0.3 & 0.2 & 0.7 & -0.7 & 0.4 & 1.5 \\
\hline 10 & -0.5 & 0.3 & 0.9 & -1.2 & 0.7 & 1.9 \\
\hline 20 & -0.8 & 0.5 & 0.7 & -1.8 & 1.1 & 1.5 \\
\hline 30 & -1.3 & 0.9 & 0 & -2.9 & 2.0 & 0 \\
\hline 40 & -2.1 & 0.3 & -1.2 & -4.7 & 0.6 & -2.6 \\
\hline 50 & -3.5 & -2.0 & -3.0 & -7.8 & -4.5 & -6.6 \\
\hline 60 & -5.5 & -5.5 & -5.3 & -11.9 & -11.9 & -11.6 \\
\hline 70 & -4.9 & -4.9 & -4.9 & -10.7 & -10.7 & -10.6 \\
\hline 80 & -2.9 & -2.9 & -2.9 & -6.2 & -6.2 & -6.2 \\
\hline \multicolumn{7}{|l|}{ Future } \\
\hline generations & 4.2 & 1.8 & 0.8 & 9.0 & 3.8 & 1.9 \\
\hline
\end{tabular}


that Medicare grows at a rate 2 percent or 4 percent faster than GNP until 2020. Not surprisingly, the burden on future generations grows considerably under these assumptions, but the extent of this growth depends on the policy being simulated. If Medicare costs rise at a rate 2 percent faster than GNP and benefits are eventually cut (in 2020), the added burden on future males would rise from $\$ 3,300$ to $\$ 12,600$; that on females from $\$ 1,800$ to $\$ 6,000$. At the other extreme, the "worst case" scenario is when Medicare grows at a $4 \%$ faster rate until 2020 , and only future generations pay. In this case, the added burden on future males rises from $\$ 19,400$ to $\$ 62,100$, that on females from $\$ 9,000$ to $\$ 26,200$. Given that our baseline simulations assign future males and females total fiscal burdens of $\$ 89,500$ and $\$ 44,200$, respectively, we see that sustained Medicare growth has the potential of absorbing a significant share of the government's overall budget.

\section{CONCLUSION}

We have estimated that the United States' policy path, based on current law and the assumption of balanced growth in government spending, will place a roughly 21 percent larger growth-adjusted net tax burden on future generations than it will place on Americans who have recently been born. But this estimate is based on what may be relatively optimistic assumptions: That the social security system's projected cash-flow surpluses will continue to accumulate and that Medicare spending will immediately stabilize as a share of GNP. Those individuals coming in the future as well as today's infants and young children could end up paying considerably more under less optimistic but realistic alternative paths for social security and Medicare policies.

Specifying a different path for payroll taxes or Medicare costs is not enough to describe an alternative fiscal policy: one must also indicate how the government will compensate for either of these changes in order to preserve intertemporal fiscal balance. Though we know some balancing response must occur, the utimate path cannot, of course, be known with certainty; we have considered several alternatives in each case.

The social security policies we have analyzed include short-term payroll tax cuts financed by long-term payroll tax increases, future benefit cuts, or general revenue finance, as well as the dissipation of the impending social security "off-budget" surpluses through increased "onbudget" deficits. Our simulations for Medicare consider alternative responses to the continued growth of Medicare expenditures as a share of GNP. The use of generational accounting reveals, as deficit account- 
ing cannot, the relative burdens that these different policy responses place on different generations.

\section{REFERENCES}

Auerbach, Alan J., Jagadeesh Gokhale, and Laurence J. Kotlikoff (1991). "Generational Accounts: A Meaningful Alternative to Deficit Accounting." In Tax Policy and the Economy. David Bradford, ed. National Bureau of Economic Research, vol. 5, 55-110.

(1992). "Generational Accounting-A New Approach to Understanding the Effects of Fiscal Policy on Saving." Scandinavian Journal of Economics, forthcoming.

Bohn, Henning (1991). "The Sustainability of Budget Deficits in a Stochastic Economy." Working paper, Wharton School, University of Pennsylvania, July.

Darman, Richard (1991). "Introductory Statement: The Problem of Rising Health Costs." Testimony presented before the Senate Finance Committee, Executive Office of the President, Office of Management and Budget, April 16, p. 6.

Kotlikoff, Laurence J. (1992). Generational Accounting-Knowing Who Pays, and When, for What We Spend. New York: The Free Press, forthcoming. 


\section{Tax}

\section{Policy}

\section{and the Economy}

Edited by James M. Poterba

National Bureau of Economic Research

Of related interest

Tax Policy and the Economy, Volume 5 Edited by David Bradford

Articles by Myron S. Scholes and Mark A. Wolfson; Hans-Werner Sinn; Alan J. Auerbach, Jagadeesh Gokhale, and Laurence J. Kotlikoff; Jonathan Gruber and Alan B. Krueger; James M. Poterba

Tax Policy and the Economy, Volume 4 Edited by Lawrence $\boldsymbol{H}$. Summers

Articles by Daniel Feenberg and Lawrence $H$.

Summers; Eytan Sheshinski; Mark Gertler and R. Glenn Hubbard; Alan J. Auerbach and Laurence ]. Kotlikoff; Lawrence $H$. Goulder

The MIT Press, Cambridge, Massachusetts 02|42 